\author{
PIOTR KRASNY \\ Instytut Historii Sztuki \\ Uniwersytet Jagielloński w Krakowie \\ Grodzka 53, 31-001 Kraków \\ E-mail: piotr.krasny@uj.edu.pl
}

Któż chciałby patrzeć na zarazę, nie uzbroiwszy się wcześniej $w$ nadzieję? Vloers 1658

\title{
SZTUKA WOBEC EPIDEMII W EPOCE NOWOŻYTNEJ
}

\section{WSTEP}

Historycy medycyny i badacze dziejów kultury materialnej poszukuja w dziełach sztuki wiernego udokumentowania konsekwencji dawnych epidemii, a zwłaszcza wygladu zmian chorobowych na ciele poszczególnych osób oraz dramatycznych skutków, wywoływanych przez zarazy w życiu społecznym. Kwerendy te moga przynieść znaczace rezultaty, ponieważ w nowożytnych obrazach i rzeźbach znajdujemy sporo realistycznych przedstawień objawów dżumy, a zwłaszcza szczególnie przerażających dymienic (BERGOLDT 2006). Takie zmiany ukazywano przede wszystkim na ciałach chorych i zmarłych na zarazę, za którymi wstawiają się święci orędownicy. Wyraźne oznaki dżumy można też dostrzec na przedstawieniach zakażonych, którymi opiekują się św. Roch z Montpellier (ok. 1350-1378), św. Karol Boromeusz (1538-1584), św. Kamil de Lellis (1550-1614) (MARTIN 2020), a potężna dymienica na udzie jest jednym $z$ najważniejszych atrybutów pierwszego $z$ tych świętych (ScHMITZ-EICHHOF 1977). Na wielu przedstawieniach św. Sebastiana, czczonego jako szczególny patron od zarazy, ślady ran od strzał na jego ciele były upodobnione do dymienic (Mollaret i BRossollet 1965). Takich manipulacji dokonywano nawet na ranach ukrzyżowanego Chrystusa w przed- stawieniu zwanym Pestkreuz (krucyfiks morowy). Na wielu obrazach wotywnych, fundowanych przez ozdrowieńców $z$ zakażenia dżuma, ukazywano znaki przypadłości, z których mieli oni zostać cudownie uwolnieni (GATTA 1998). W nielicznych dziełach można odnaleźć też świadectwa bezowocnych prób leczenia dżumy. Na przykład na obrazie Luki Giordana (1634-1705), przedstawiajacym św. Januarego orędującego za zakażonymi w Neapolu, jeden $z$ trupów, leżący $u$ stóp tego patrona, ma ponacinane dymienice (patrz Ryc. 2C) (BOECKL 2000).

Znacznie większa ostrożność należy jednak zachować szukając w dziełach sztuki wiarygodnych przedstawień zachowania ludzi, doświadczających okropności epidemii. Dostrzegajac na obrazie lub rycinie przedstawienie niemowlęcia odciaganego od piersi zabitej przez zarazę matki, można je uznać za wierne odwzorowanie sceny, która artysta zaobserwował na ulicy dotkniętego przez zarazę miasta. Okazuje się jednak, że to poruszajace wyobrażenie pojawia sie na niemal wszystkich nowożytnych dziełach przedstawiajaccych zarówno współczesne zarazy, jak i pomory sprzed kilku wieków lub $z$ epoki starożytnej. Mamy więc tu do czynienia $z$ konwencją ikonograficzna, wprowadzona już w IV stuleciu przed Chrystusem przez Arystydesa $z$ Teb, na obrazie znanym dzięki opisom Pliniusza Młodszego (61-113) (SCHÜT-

Słowa kluczowe: epidemia w sztuce nowożytnej, religia wobec epidemii, władze państwowe wobec epidemii, wpływ epidemii na architekturę 


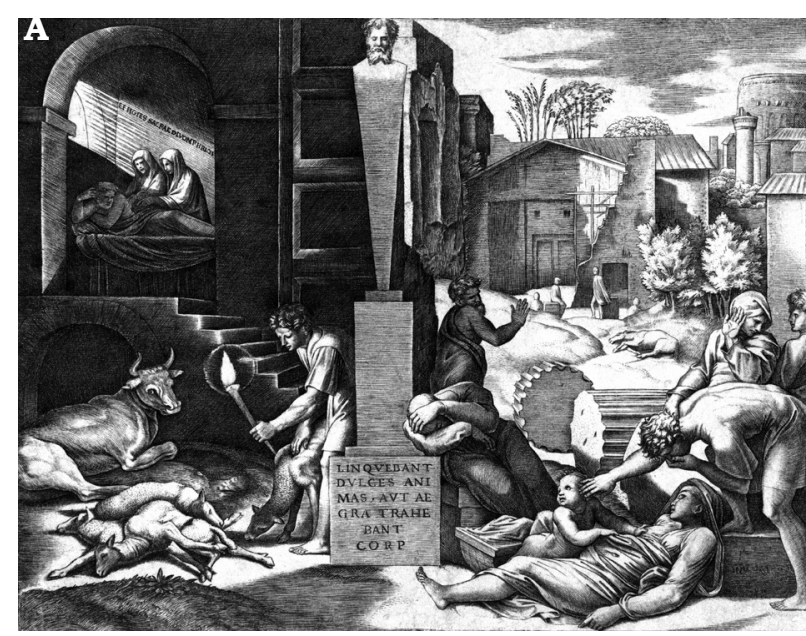

B

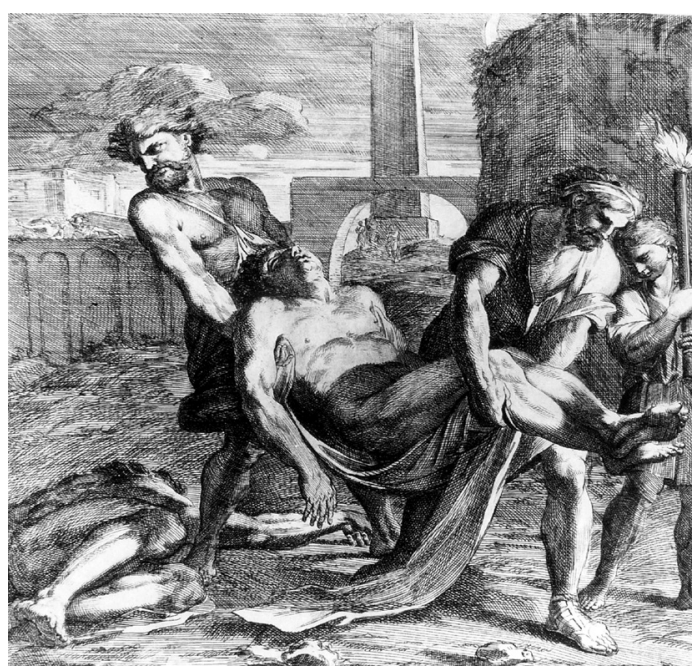

$\mathbf{C}$

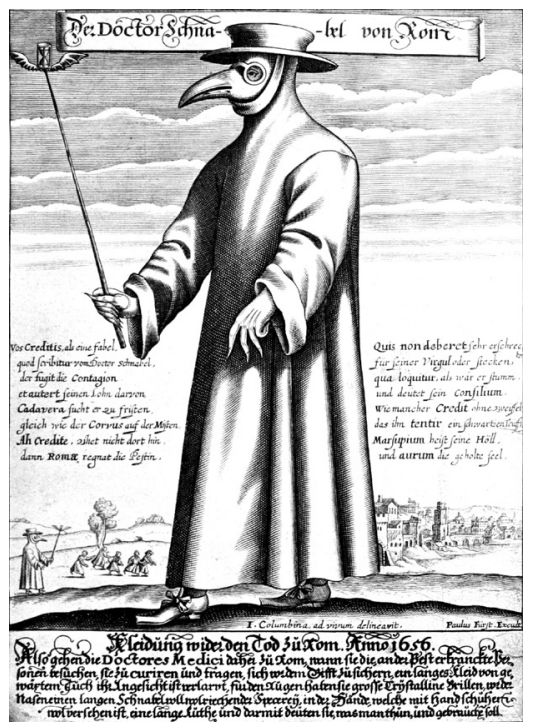

Ryc. 1. Prawdziwe (?) obrazy epidemii. A) Marcantonio Raimondi wg Rafaela, Morbetto (Zaraza $w$ Pergamie), miedzioryt, około roku 1519. B) Guillaume Courtois, Zaraza, akwaforta, po 1656. C) Paul Fürst wg J. Colombiny, Medyk $w$ trakcie zarazy $w$ Rzymie $w$ roku 1656, miedzioryt.
ZE i VIREY-WALLON 1996). Na poczatku XVI w. ujęcie to zostało przypomniane w rycinie Marcantonia Raimondiego (ok. 1480 - ok. 1530), wykonanej na podstawie projektu Rafaela (1483-1520) (Ryc. 1A) i było $z$ niej „przerysowywane” z mniejsza lub większa wiernością w licznych dziełach (Wouk 2016).

Wiele wskazuje na to, że ów miedzioryt zasugerował także wielu artystom przedstawienie dwóch mężczyzn, wynoszących niedbale nagie ciało ofiary epidemii, trzymając je pod pachy i pod kolana (Ryc. 1B). Takie ujęcie zdaje się ilustrować dość dobrze relacje pisane o obcesowym traktowaniu zwłok zakażonych (LOLLOBRIGIDA 1998), ale pozostaje w sprzeczności $z$ licznymi przedstawieniami grabarzy, przenoszacych takie ciała na marach, nakrytych płótnem rozciagniętym na kabłąkach. Badacze historycznej ikonografii epidemii muszą więc zastanawiać się, czy rafaelowskie przedstawienie traktowania zwłok ma istotna wartość dokumentacyjna, czy też jest swoista fantazja tego artysty, mająca poruszać emocje widzów.

W wielu wydawnictwach na temat nowożytnych epidemii zreprodukowano miedzioryt Paula Fürsta (1608-1666) według rysunku J. Colombiny z 1656 r., przedstawiajacy rzymskiego lekarza, zabezpieczającego się w trakcie epidemii przed zakażeniem długa powłóczystą szatą oraz metalowa maska $z$ okularami i specjalnym dziobem, przeznaczonym do palenia ziół, mających oczyszczać powietrze (Ryc. 1C). Rycina ta jest traktowana jako świadectwo wyglądu ubioru ochronnego używanego powszechnie przez nowożytnych medyków (MOLlaRET i BROSSOLlET 1965, CipPola 1981), choć istnieje bardzo wiele obrazów, przedstawiajacych lekarzy, badajacych zakażonych bez żadnego zabezpieczenia (HENDERSON 2019). Spostrzeżenie to nie dowodzi, rzecz jasna, braku wartości dokumentacyjnej dzieła Fürsta, ale skłania do postawienia kwestii, czy w różnych publikacjach nie uogólniono przesadnie jego przekazu.

W badaniach ikonograficznych dotyczących nowożytnych zaraz natrafiamy często na takie pytania, nie dysponujac metodami pozwalajaccymi na ich jednoznaczne rozstrzygnięcie. Przede wszystkim musimy jednak pamiętać, że traktując dzieła sztuki wyłącznie jako wierne przedstawienia zarazy, postępujemy wbrew intencjom ich zleceniodawców i twórców. W epoce nowożytnej podzielano powszechnie opinie humanisty i medyka Françoisa Valleriolea (1504-1580), że „zaraza jest najgorszą rzecza, która może się nam przydarzyć i dlatego nikt nie chce o niej myśleć, ani o niej pamiętać" (VALLERIOLE 1566). Trudno zatem przypuszczać, aby obrazy i rzeźby były tworzone na przekór takiej 
postawie. Można za to przyjąć tezę, że dzieła sztuki miały przede wszystkim przygotowywać ludzi do zmierzenia się $z$ nieuchronnym zagrożeniem epidemicznym i zabezpieczyć ich przed frustracja, wywoływana przez nieustanne niepowodzenia $\mathrm{w}$ zmaganiach $\mathrm{z}$ zarazą lub w próbach ograniczenia jej potężnej niszczacej mocy (AURIGEMMA 1998). Należy zatem patrzeć na nie jako na wyraz stosunku ludzi do epidemii i elementy swoistego politycznego programu, mającego maskować bezsilność władz religijnych i państwowych wobec takiego zagrożenia.

\section{NATURALNA CHOROBA \\ I NADPRZYRODZONE LEKARSTWA}

W okresie średniowiecza podzielano zgodnie naukę, zaczerpnięta ze Starego Testamentu, że zaraza jest kara zsyłana przez Boga za zbiorowe grzechy społeczeństwa. Za oczywisty i skuteczny sposób na jej powstrzymanie uważano zatem powszechne nawrócenie i zbiorową pokutę (DI VEROLI 2014, MARTIN 2020). Ów klarowny program zmagania się $z$ epidemiami załamał się jednak w epoce nowożytnej. Coraz powszechniej zaczęto akceptować w niej opinię antycznych lekarzy: Hipokratesa (ok. 460-375 p.n.e) i Galena (ok. 129-216), że epidemie sa wywoływane przez naturalne przyczyny, mianowicie zepsucie powietrza „waporami" lub jego nasycenie śmiercionośnymi „nasionkami”. Pogląd ten, przypomniany i wnikliwie uzasadniony przez Girolama Fracastora (1478-1553) w połowie XVI stulecia (FRACASTOR 1546), został w ciagu pięćdziesięciu lat zaakceptowany nie tylko przez większość medyków, ale także przez licznych swiatłych duchownych (GAzZANIGA 1998, JORI 2020).

Uznaniu epidemii za zjawisko naturalne nie towarzyszyło jednak odkrycie naturalnych leków na choroby zakaźne. W dalszym ciagu błagano więc usilnie Boga, aby powstrzymał rozchodzenie się zepsutego powietrza, proszac już nie o zmiłowanie, ale o łaskawe odwrócenie porządku natury, czyli dokonanie cudu (BERGOLDT 2006, MARTIN 2020). Duchowni zachęcali zatem wiernych do ponawiania usilnych próśb o taka Boża interwencje, powtarzajac, tak jak augustianin $z$ Sewilli Francisco de Silverstre w 1679 r., na poły retoryczne, a na poły naznaczone desperacja pytanie: „Kto nas uwolni od zarazy, kto sprawi, że nie wejdzie przez nasze bramy i nie przeskoczy przez mury naszego miasta, jeśli nie miłosierny Bóg?” (NUÑEZ BELTRÁN 2000).

Przekonanie, że tylko Stwórca może uleczyć zarażanych, wyrażano też w dziełach sztuki, takich jak obraz wotywny padew- skiej rodziny Papafava, namalowany przez Lukę Ferrariego (1605-1654). Na obrazie tym przedstawiono medyków, przyglądających się wnikliwie dymienicy na ciele młodzieńca jako symptomowi zapadnięcia przez niego na dżumę. Jako rzeczywista przyczynę uzdrowienia tego nieszczęśnika upamiętniono jednak wstawiennictwo św. Dominika i modlitwę na różańcu, podawanym $z$ niebios przez Matkę Boska i aniołki (FURLAN i MASON 1998). Podobne pouczenie zawarł Petrus Vloers w poetyckim opisie zarazy w Limoiges, w trakcie której dominikański kaznodzieja pouczył lud, że skoro medycy nie sa w stanie powstrzymać epidemii, to „trzeba błagać Boga, aby odwrócił tę plagę| i prosić Marię, aby wstawiła się za ludem. Jest zaś jasne, że najlepiej uczynić to za pomoca różańca." Zakonnik ten okazał się „prawdziwym lekarzem”, ponieważ jego „uzdrawiające słowa" sprawiły, że wierni zaczęli modlić na różańcu ze łzami, wypraszając ustanie zarazy (VlOERS 1658). Dołaczona do wiersza Vloersa miedziorytnicza ilustracja Richarda Collina (1626-1698) według projektu Erasmusa Quellina (1607-1678), przedstawiajaca dominikanina ukazującego zadżumionym różaniec i niebiańskich adresatów modlitwy różańcowej (Ryc. 2A), przyczyniła się do znacznego rozpropagowania tego remedium w Niderlandach, ponieważ jej ikonografia i kompozycja była powielana w licznych dziełach sztuki, m.in. w reliefie w stallach w Sint-Pauluskerk w Antwerpii (DE COO 1965).

O ile w epoce nowożytnej nie wytworzono naturalnych leków na choroby zakaźne, o tyle znano środki spowalniajace ich rozprzestrzenianie, takie jak ograniczenie ruchliwości społecznej, izolacja zainfekowanych i sprawne grzebanie zmarłych. Do jak najpowszechniejszego stosowania tych środków wzywali nie tylko lekarze, ale także najbardziej wpływowi duchowni, a jedno z najważniejszych dzieł na ten temat zostało ogłoszone w 1684 r. przez arcybiskupa Benewentu kardynała Girolama Gastaldiego (1616-1685) (GASTALDI 1684). Hierarcha ten pouczał, że zwalczanie epidemii środkami politycznymi i prawnymi jest bardzo uciązliwe dla społeczeństwa, dlatego trzeba przekonywać je usilnie o skuteczności przedsięwzięć, dla których ponosi ono tak wielkie ofiary. Należy też szczególnie zachęcać ludzi do angażowania się w działania instytucji podejmujacych bezpośrednia pracę $z$ chorymi lub $z$ ich szczattkami, podkreślajacc heroiczny charakter takich działań (SonNino 1998).

Już po epidemii dżumy we Włoszech w 1630 r. takie instytucje zamawiały obrazy przedstawiajace ich bohaterskie akcje, aby wykorzystać te malowidła przede wszystkim 


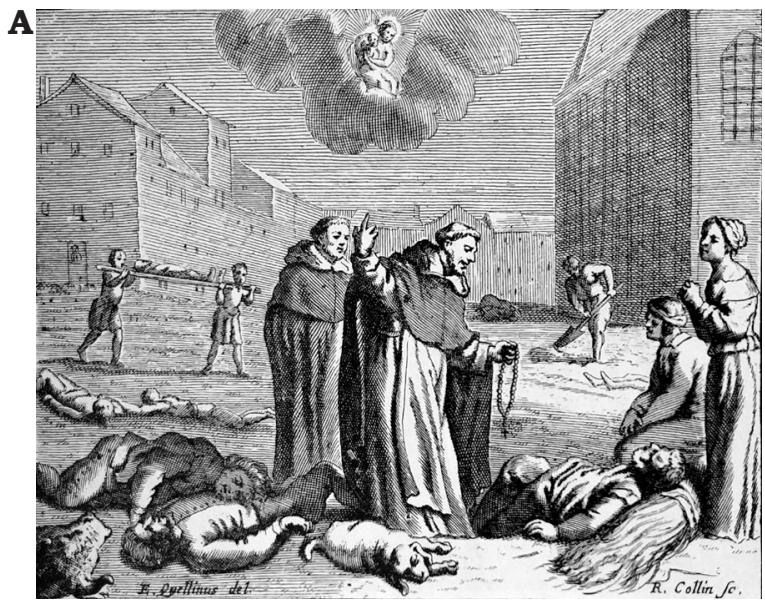

C

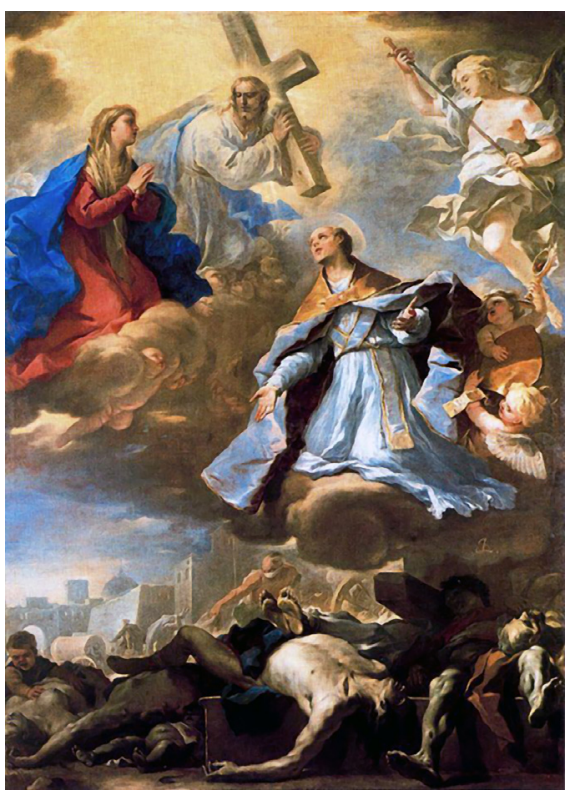

do zachęcania przyszłych członków do gorliwego zmagania się $z$ przyszłymi zarazami. Kamilianie $z$ Bolonii zapatrzyli się na przykład w obraz przestawiający ich współbraci $\mathrm{w}$ sutannach $\mathrm{z}$ czerwonymi krzyżami, zbierających $z$ ulicy liczne ciała i próbujących udzielić pomocy chorym, leżącym przed domami (MANZI 1967). Florencka Arciconfraternita della Misericordia zamówiła zaś u Baccia del Bianco (1604-1656) okazałe malowidło ukazujace należacych do niej medyków i grabarzy, zmagających się ze skutkami epidemii na Piazza del Duomo. W obrazie tym oddano bardzo wyraziście metodyczność i profesjonalna staranność członków arcybractwa, które były opisane $z$ podziwem $w$ relacjach o pladze we Florencji (HENDERSON 2019).

Obraz pokazujacy wywożenie $z$ rzymskiego Zatybrza w 1656 r. zakażonych i zmarłych na dżumę pod nadzorem specjalnej komisji sanitarnej, sławił nie tylko działania tej instytucji, ale także władze Państwa Kościelnego, które powołały ją do życia. Na
B

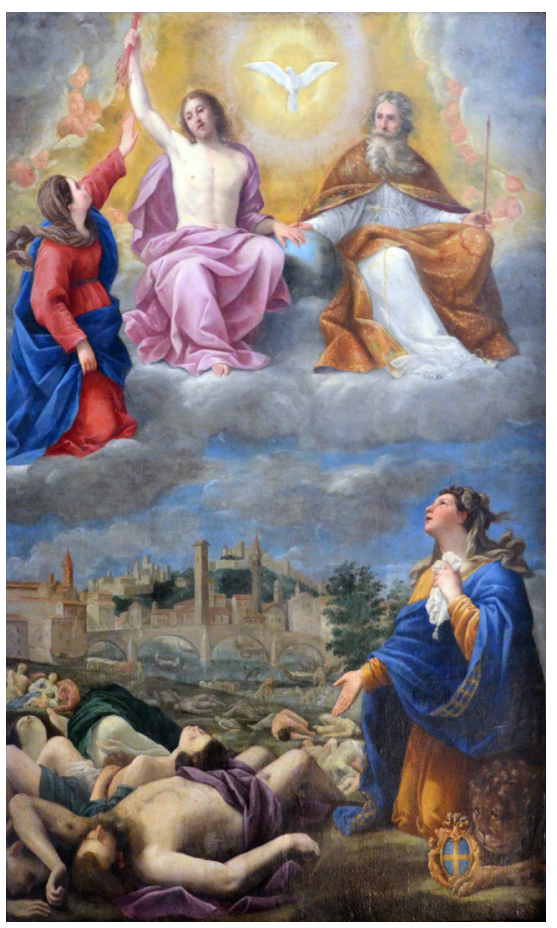

Ryc. 2. Nadprzyrodzone lekarstwa na naturalna chorobę. A) Richard Collin wg Erasmusa Quellina, Dominikanin zachęcajacy zakażonych w Limoiges do modlitwy na różańcu, miedzioryt, 1658. B. Antonio Giarola zwany Cavalier Coppa, Obraz wotywny na ustanie epidemii $w$ Weronie, olej na płótnie, po roku 1630, kościół San Fermo Maggiore w Weronie (fot. Michał Kurzej) C) Luca Giordano, Św. January wstawiajacy sie za zadżumionymi neapolitańczykami, olej na płótnie, 1662, Museo di Capodimonte w Neapolu (fot. Il Sistemone, licencja $\mathrm{CC}$ ).

skraju zapowietrzonej dzielnicy przedstawiono bowiem papieskiego prefekta kardynała Gulia Cesara Sachettiego (1586-1663) w trakcie wizytowania służb medycznych i porzadkowych. Obraz akcentował więc bardzo mocno znaczenie władzy $\mathrm{w}$ zmaganiach $\mathrm{z}$ epidemią, podkreślając jednak równie zdecydowanie, że może ona osiagnać sukces tylko wtedy, kiedy gorliwe ludzkie wysiłki skłonia Stwórce do cudownego wygaszenia zarazy. Taka naukę przekazuja bowiem otwarte niebiosa nad Zatybrzem, w których widać Chrystusa, Marię, anioły i świętych, orędujacych u Boga Ojca nad nieszczęsna dzielnica (Micheli 1998). Obraz jest więc także jednym $z$ licznych dzieł powstających w epoce nowożytnej, które miały utwierdzać $\mathrm{w}$ ludzie przekonanie, że nadprzyrodzona interwencja Najwyższego jest nie tylko nieodzowna do pokonania epidemii, ale także możliwa do wyproszenia poprzez gorliwe modlitwy Kościoła wspieranego przez swoich niebiańskich orędowników. 


\section{OBRAZY LUDZKICH STARAŃ} I NIEBIAŃSKIEGO WSPARCIA

Co najmniej od połowy XV w. rozpowszechniły się obrazy, przedstawiające świętych wstawiających się na klęczkach przed Chrystusem za ukazane poniżej nich miasta dotknięte przez zarazę. $Z$ wyobrażeń tych miejscowości można było wyczytać, że ich mieszkańcy poddają się biernie nieszczęściu uznawanemu za karę Bożą, leżąc lub błąkając się wśród ciał swoich sąsiadów. Po 1600 r. zaszła zasadnicza zmiana w ikonografii dolnej części tych dzieł, ponieważ zaczęto ukazywać w nich ludzi zmagających się intensywnie $z$ epidemią i czerpiących siły $z$ niebiańskiego wsparcia (BOECKL 2000). Na namalowanych przez Guida Reniego (15751642) sztandarze wotywnym za ustanie zarazy w Bolonii w 1630 r. widzimy grabarzy usuwajacych sprawnie ciała zadżumionych na wozach lub na marach nakrytych całunami. Ich pełną poświęcenia pracę wspomagaja znajdujący się za bolońskimi murami zakonnicy wznoszacy ręce ku niebiosom, w których patroni miasta prosza $z$ wielkim zaangażowaniem Dziecię Jezus o cudowną interwencję. Można zatem stwierdzić, że malowidło Reniego zrównywało bezpośrednie zmagania $z$ zaraza $z$ intensywnymi modlitwami o jej wygaśnięcie pokazując, że oba te działania wyrywaja ludzi $z$ apatii $i$ daja im (w tym wypadku niezawiedziona) nadzieję na przezwyciężenie straszliwej plagi (PUGLISI 1995).

Niektóre działa sztuki pouczały widzów, że nawet pozornie desperackie próby zmierzenia się ze skutkami epidemii moga przynieść sukces, o ile wątłe ludzkie siły zostana wsparte nadprzyrodzona pomoca $z$ niebios. Na obrazie Antonia Giaroli zwanego Cavalier Coppa (ok. 1595-1665) w kościele w San Fermo Maggiore w Weronie przedstawiono nielicznych grabarzy próbujacych usunać wielka liczbę zwłok $z$ łąki nad Adyga, na której izolowano chorych w 1630 r. (Ryc. 2B). Praca ta zdaje się być ponad ich siły, ale wsparta modlitwa personifikacji Werony skłania Matkę Boska do dramatycznego upraszania Syna o powstrzymanie zarazy niszczacej to miasto (ECONOMOPOULOS 1998). Jeszcze bardziej wymowne zestawienia pozornie desperackich ludzkich wysiłków $Z$ nadzwyczajna pomoca $z$ niebios dostrzegamy na obrazie Domenica Gargiula zwanego Micco Spadaro (ok. 1609-1675) w kartuzji San Martino w Neapolu, pokazujacym zmagania $z$ epidemią $\mathrm{w}$ tym mieście w $1656 \mathrm{r}$. W przerażajacy sposób prezentuje się na nim rozległa przestrzeń przed murami miasta, zasłana setkami trupów, które staraja się usuwać wychudzeni i słaniajacy się na nogach grabarze i żołnierze (PORZIO 1984). Obraz potwierdza jednak relacje, że ci niemal bezsilni ludzie „znajdowali pociechę w religii" (RELAZIONE 1661), pokazując wsparcie ich pracy przez Matkę Boska, wstawiajaca się za nimi u Chrystusa.

Szczególnym przykładem heroicznej walki $z$ epidemia środkami naturalnymi, a zarazem zawierzenia $\mathrm{w}$ tym działaniu Bożej Opatrzności, był arcybiskup Mediolanu Karol Boromeusz. W czasie epidemii w tym mieście w 1576 r. starł się on zapewnić chorym i izolowanym dach nad głowa oraz żywność i opiekę duszpasterska, a nawet osobiście dowoził im prowiant i udzielał sakramentów. $Z$ równym zaangażowaniem oddawał się także modlitwom o ustanie epidemii, spędzając na klęczkach wiele godzin przed relikwia gwoździa z krzyża Pańskiego. Jeden i drugi sposób zmagań Boromeusza $z$ epidemia były wielokrotnie ukazywane w jego ikonografii rozpowszechnionej w licznych krajach europejskich, jakkolwiek jego fizycznych i duchowych zmagań nie przedstawiono zwykle na tym samym obrazie lub rycinie (JonES 2005, DOMPNIER 2006).

Podejmowanie coraz intensywniejszych i bardziej przemyślanych prób walki $z$ zarazami w epoce nowożytnej uświadomiło potrzebę stworzenia w miastach swoistej infrastruktury epidemicznej, w skład której wchodziły także trwałe budowle i założenia przestrzenne. Charakterystyczna dla tej epoki, szeroko rozpowszechniona „kultura pamięci" (EMISON 2012), skłaniała również do uwieczniania pomorów jako straszliwych, ale zarazem bardzo ważnych wydarzeń za pomoca różnorodnych pomników architektonicznych. Wszystkie te struktury musiały być jednak pomyślane w taki sposób, aby nie straszyć ludzi powracajaca co pewien czas plaga, ale żeby utwierdzić ich w przekonaniu, że w razie takiego nawrotu będa mogli liczyć na pomoc instytucji państwowych i kościelnych (DINGES 1995), a po tych ostatnich spodziewać się wyproszenia nadprzyrodzonego wsparcia.

\section{LAZARETY JAKO DEMONSTRACJA TROSKI WŁADZ O ZAKAŻONYCH}

Biblijna Księga Kapłańska $(13,46)$ nakazywała, aby osoba dotknięta trądem przebywała w odosobnieniu, poza obozem Izraelitów. W epoce nowożytnej zasadę tę rozciagano na wszystkie osoby chorujące zakaźnie, usuwajac je poza przestrzeń miejską. Miejsca, w których grupowano chorych, nazywano izolatoriami i $z$ reguły poświęcano bardzo mało wysiłku i środków na ich urządzenie. Podczas epidemii dżumy, nękającej Weronę w 1630 r., poprzestawano na wywoże- 
niu zakażonych i podejrzanych o zakażenie na łąkę po drugiej stronie Adygi, na której pozostawiano ich bez żadnego schronienia przed niepogoda, co zostało udokumentowane na wspomnianym już obrazie Cavaliera Coppy (Ryc. 2B) (ECONOMOPOULOS 1998). Sztandar wotywny, ofiarowany do katedry w Trydencie, zaświadczał, że pod tym miastem zadbano nieco lepiej o urządzenie izolatorium, umieszczając chorych w wielkich beczkach położonych na boku, z których mogli oni uczestniczyć w mszy, odprawianej na ołtarzu polowym, a także oglądać palenie ciał na wielkim stosie (FOLGHERAITER 1994).

Ze znacznie większą starannością urzadzono izolatorium w Mediolanie w 1576 r., budujac na polach pod miastem 559 szałasów $z$ drewna i 3188 szałasów z trzciny na pomieszczenie bardzo licznych ofiar dżumy (Ryc. 3A) (Rossi DI MARIGNANO 2010). Drobiazgowe i zapewne wierne odwzorowania tych konstrukcji wkomponowano po kilkudziesięciu latach w obrazy przedstawiajace sw. Karola Boromeusza, udzielającego sakramentów zadżumionym, oraz w niektóre lombardzkie wyobrażenia św. Rocha (BURZER 2011). Owe prowizoryczne budynki utrwaliły się jednak w pamięci mediolańczyków nie tyle jako przykład dobroczynnej inicjatywy, ile jako koszmarny wyraz rozmiarów zarazy, w czasie której potrzebowano tysięcy miejsc dla śmiertelnie chorych.

Karol Boromeusz, uświadomiwszy sobie ponura wymowę izolatorium, postanowił zatem zastapić je solidna murowana budowla (Ryc. 3B), w której można byłoby zapewnić nieco lepszą opiekę chorym, a zarazem ukryć ich liczbę przez oczami innych mieszkańców Mediolanu. W tym celu zainicjował przebudowę piętnastowiecznego leprozorium zwanego lazzaretto (od imienia patrona trędowatych sw. Łazarza), na miejsce odosobnienia dla zarażonych lub podejrzewanych o zarażenie dżumą. Przy długich na 400 prętów (około 365 metrów) portykach, ujmujących dziedziniec leprozorium, architekt Pellegrino Tibaldi (1527-1596) wybudował ciagi ogrzewanych i skanalizowanych izb $z$ solidnymi drzwiami oraz okienkami do podawania doczesnej strawy i Eucharystii. Pośrodku dziedzińca wzniósł ponadto kościół na planie ośmioboku, którego ściany były przeprute wielkimi arkadami, dzięki którym izolowani mogli obserwować sprawowanie mszy, a jej celebrans miał być chroniony przed zakażeniem dzięki przepływowi świeżego powietrza (CAVEnago 1986).

Giovan Pietro Giussano (1553-1623), sekretarz i jeden $z$ pierwszych biografów Boromeusza odnotował, że współcześni arcybiskupa mediolańskiego odczytali wiernie oraz docenili praktyczne i symboliczne funkcje przypisane przez niego lazzaretto. Uznali bowiem, że budowla bardzo skutecznie „separuje zakażonych od codziennego życia miejskiego", a zarazem jest wymownym widzialnym wyrazem „żarliwego umiłowania swojego ludu" przez Boromeusza (GiUssano 1610). Nie należy się więc dziwić, że zaczęto naśladować lazzaretto w wielu miastach, wnoszac w nich okazałe budowle, będace wyrazem troski o lud dotykany co pewien czas straszliwą zarazą. Domy zakażonych funkcjonowały wprawdzie we Włoszech już od XV w., ale od schyłku następnego stulecia zaczęto nazywać wszystkie takie budynki lazaretami, wskazując na mediolański gmach jako wzorzec dla ich nowożytnego ukształtowania i przekazu ideowego.

Nowożytne lazarety miały, tak jak okazała mediolańska instytucja zorganizowana przez Boromeusza, przekonywać ludzi, że w sytuacji zagrożenia epidemicznego nie sa oni pozostawieni sami sobie, ale moga liczyć na wsparcie władz państwowych, miejskich lub kościelnych, zapewniajacych opiekę tak rzetelna, jak solidne sa gmachy służace jej sprawowaniu (UlBRICHT 2004). Większość tych budynków wznoszono wokół prostokątnego (lub rzadziej pięciobocznego) dziedzińca, otaczajacego go $z$ czterech stron dwulub nawet trójkondygnacyjnymi skrzydłami i budujac na jego środku ażurowa kaplicę nakrytą kopuła (Ryc. 3C). Do budowy lazaretów angażowano wybitnych architektów, takich jak twórca domu dla zakażonych w Anconie Luigi Vanvitelli (1700-1773), i nie skapiono środków na ich zewnętrzną ozdobę, wzbogacając bryły narożnymi wieżami i okazałymi bramami, a także nakładając na elewacje podziały architektoniczne (STEVENS CRAWSHAW 2012), a czasem także efektowną dekorację rzeźbiarską, czego przykładem może być relief Rombouta Verhulsta (16241696) na fasadzie Pesthuis w Lejdzie, wykonany w 1660 r. (MOLLARET i BROSSOLLET 1965).

Zupełnie inaczej wyglądały jednak wnętrza lazaretów, nie służące propagandzie, ale izolacji chorych, zmierzającej nie tylko do ograniczenia szerzenia się zarazy, ale także do ukrycia cierpień jej ofiar przed zdrowa czéścia społeczności. Taka funkcję mogły zaś pełnić surowe przestrzenie bez żadnych dekoracji, których wygląd nie był zbyt dobrze znany społeczeństwu, ponieważ większość osób, umieszczanych w lazaretach, trafiała $z$ nich prędko do masowych grobów na pobliskim cmentarzu. Losu tego uniknał jednak Jean-Jacques Rousseau (1712-1778), kiedy w 1743 r. został skierowany na kwarantannę do „wielkiego dwupiętrowego gmachu” lazaretu w Genui. Lazaret ten po niedawnej przebudowie prezentował się bardzo okazale, 
A
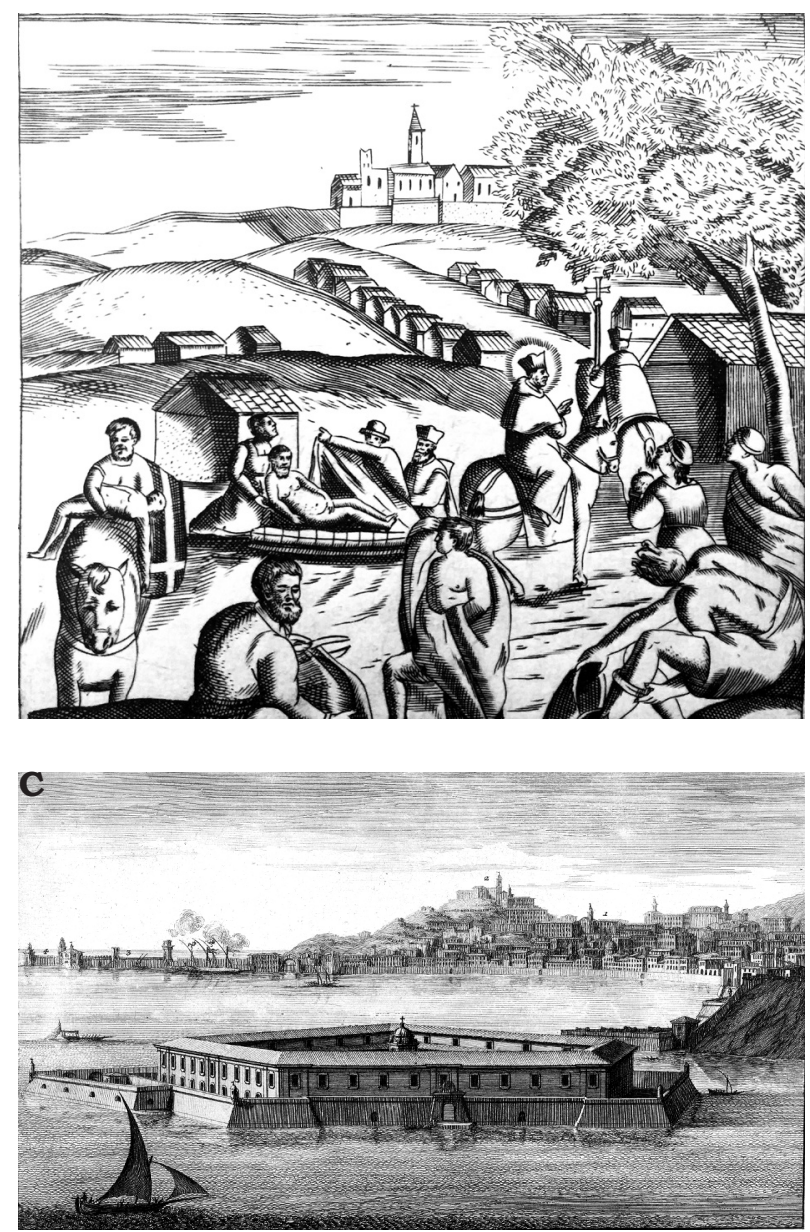

D

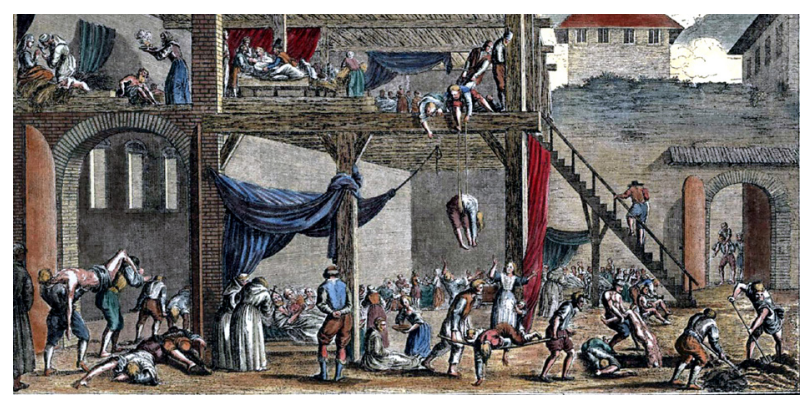

ale wewnattrz nie miał nawet podstawowego wyposażenia. Rousseau po opuszczeniu genueńskiej instytucji obwieścił więc: „nie zastałem tam ani łóżka, ani krzesła, ani nawet zydla, żeby przysiąść, ani wiazki słomy, żeby się położyć. Przyniesiono mi płaszcz, worek podróżny i dwie walizki; zamknięto za mną duże drzwi o potężnych zamkach" (RoUSSEAU 1978).

W czasie nasilenia epidemii w lazaretach brakowało nie tylko mebli, ale także miejsca dla licznych chorych, co udokumentowano na przedstawieniach smutnego losu ofiar zarazy, którym w ostatnich chwilach życia zabrakło należytej opieki. Daniel Mikołaj Chodowiecki (1726-1801) na miedziorytniczej ilustracji do elementarza Johanna
B

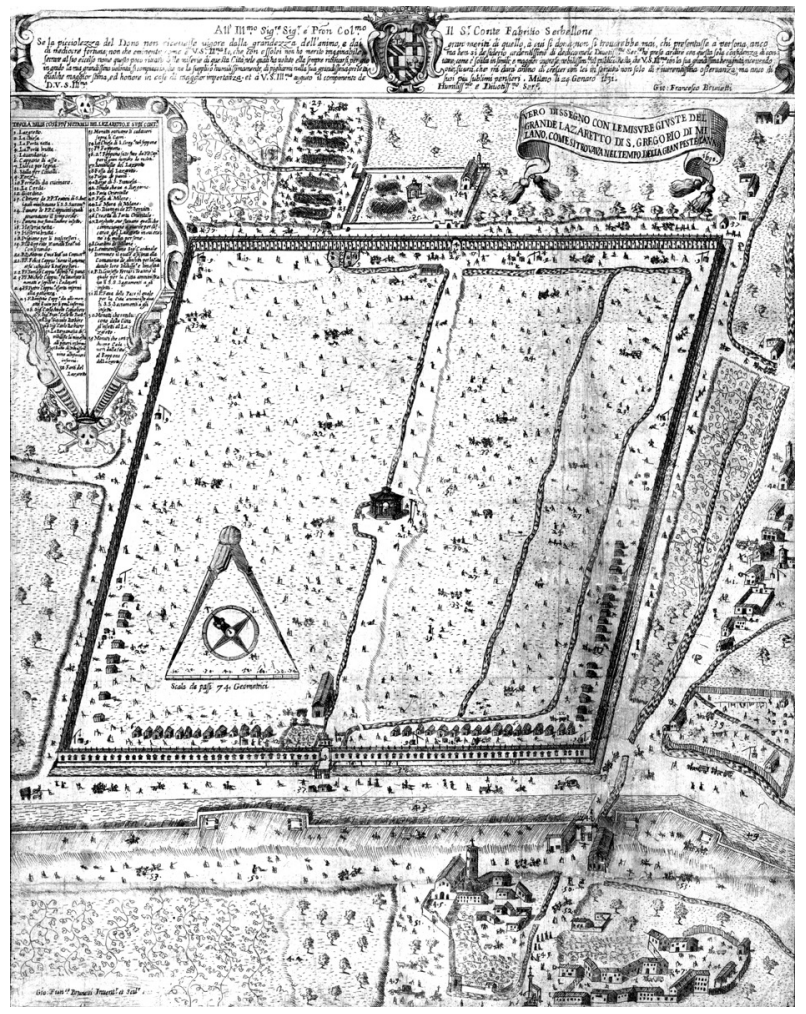

Ryc. 3. Izolatoria i lazarety. A) Izolatorium w Mediolanie w czasie epidemii w roku 1576, fragment miedziorytu Alberta Ronchiego, Św. Karol Boromeusz nawiedzajacy zakażonych, 1610. B) Lazaret $w$ Mediolanie, miedzioryt, 1630. C) Giuseppe Vasi wg Giovanniego Domenica Capiglii, Lazaret $w$ Ankonie, miedzioryt, 1739. D) Ludovico Burnacini Lazaret $w$ Wiedniu $w$ czasie epidemii $w$ roku 1679, miedzioryt kolorowany, 1679.

Bernharda Basedowa (1724-1790) z 1774 r. przedstawił dwóch chorych, położonych w jednym ciasnym łóżku, i trzeciego, który kona na podłodze wsparty o ten mebel, tuż obok zmarłego, przykrytego prześcieradłem (BASEDOW 1774). Na rycinie Ludovica Burnaciniego (1636-1707), wyobrażającej przekrój wiedeńskiego lazaretu $\mathrm{w}$ trakcie zarazy w 1679 r. (Ryc. 3D), ukazano nie tylko stłoczenie chorych, umierających i trupy we wnętrzu tego budynku, ale także niezbyt delikatne traktowanie zwłok, które sa spuszczane $\mathrm{z}$ piętra na linie zawiazanej $\mathrm{w}$ pasie, i wynoszone niedbale do pobliskiego masowego grobu (MOLLARET i BROSSOLleT 1965, ULBRICHT 2004). Przepełnienie wnętrz lazaretów żywymi i zmarłymi bywało też wyobrażane dosadnie $\mathrm{w}$ obrazach religijnych ukazujacych Rocha i Karola Boromeusza, niosacych pomoc zadżumionym. Takie ujęcie ikonograficzne, zastosowane m.in. przez Jacopa Tintoretta (1518-1594) w przedstawieniu patrona kościoła San Rocco w Wenecji, miało podkreślać heroizm tych świętych, popychanych przez nadzwyczajną miłość bliźniego do 
wkraczania pośród ludzi emitujących wielką ilość „miazmatów” (MASON RINALDI 1979, MARSHALL 2009).

Kontrast pomiędzy zewnętrznym i wewnętrznym wyglądem nowożytnych lazaretów nie ograniczał ich olbrzymiej roli w procesie symbolicznego opanowywania zaraz za pomoca dzieł sztuki. Mieszkańcy nowożytnych miast zgadzali się wprawdzie $z$ opiniami wypowiadanymi w 1620 r. we Florencji, że pobyt w tych gmachach ,jest straszniejszy od śmierci" (HENDERSON 2019), ale dopóki znajdowali się na zewnątrz nich, nie chcieli pamiętać, co dzieje się za murami efektownych budynków, będacych nieraz ozdoba całych dzielnic. Dzięki budowie lazaretów znacznie rzadziej oglądano umierajacych na zarazę, co mogło dawać mocno złudne przeświadczenie, że władze i służby medyczne zaczynają panować nad epidemiami.

CMENTARZE EPIDEMICZNE I KOSCIOEY WOTYWNE ORAZ ICH ROLA W KONTROLOWANIU PAMIĘCI O ZARAZACH

Najstraszniejszym obrazem towarzyszacym zarazom były niepogrzebane zwłoki zmarłych na nią osób, poniewierajace się na placach, drogach, łakkach i polach, co odnotował już Owidiusz (43 p.n.e - 17 lub 18 n.e.) w XXVII księdze Metamorfoz (BERGOLDT 2006). W anonimowej relacji o potężnym ataku dżumy na Neapol w 1656 r. zapisano, że „na ulicach nie sposób było zobaczyć niczego innego poza martwymi ciałami, co straszliwie przerażało garstkę pozostałych przy życiu, którzy nie mogli nawet mieć nadziei, że po śmierci spoczną w grobie w ziemi" (RELAZIONE 1661). Potężne sterty trupów pokazano też na licznych obrazach upamiętniajacych tę epidemię, a towarzysząca jej grozę oddawano najdosadniej ukazujac bardzo realistycznie ciała ofiar dżumy, naznaczone przedśmiertnym cierpieniem i znajdujące się w rożnym stopniu rozkładu (Ryc. 2C) (PoRzIO 1984).

Pozostawienie ciał zakażonych na ulicach uważano powszechnie za rażący wyraz bezsilności władz wobec epidemicznego zagrożenia. Na rycinach przedstawiajacych zarazę w Marsylii w 1720 r. świadomie kontrastowano efektowna wielopiętrowa zabudowe szerokich alei tego miasta $z$ porzuconymi na nich chaotycznie zwłokami, żeby uzmysłowić widzom, że nawet największa europejska potęga, która w pierwszej połowie XVIII w. było z pewnością Królestwo Francuskie, zdaje się poddawać wobec dramatycznego pomoru. Państwo zdołało jednak zażegnać ten kryzys, dzięki działaniu królewskiego komisarza Nicolasa Rozego (1675-1733). Zorganizował on „kompanię wron”, grzebiaca bardzo sprawnie tysiace trupów zalegajace w Marsylii. Działania te zostały prędko rozpropagowane przez dzieła sztuki, na których eksponowano Rozego jako reprezentanta władzy, otrząsającej się ze słabości i przywracającej poddanym nadzieję na przezwyciężenie dramatycznego doświadczenia (BERTRAND 1992).

Obserwatorów epidemii poruszało jednak nie tylko porzucanie ciał na ulicach, ale także obcesowe traktowanie szczątków przewożonych bez szacunku lub wręcz włóczonych do masowych grobów „w polu”, a następnie zagrzebywanych bez żadnych ceremonii religijnych (GENTILCORE 2013). Taki sposób działania kompromitował szczególnie władze kościelne, które w spokojniejszym czasie przypominały o obowiąku godnego traktowania ciał zmarłych obawiajacc się, że odmienne postępowanie $z$ nimi może osłabić wiarę $\mathrm{w}$ nieśmiertelność duszy i nadzieję zmartwychwstania. W trosce o podtrzymanie morale mieszkańców Mediolanu w czasie zarazy dżumy w 1567 r. Boromeusz zatroszczył się więc także o budowę tuż za bramami miejskimi trzech cmentarzy epidemicznych, na których poświęcona ziemia została otoczona portykami kolumnowymi, a sakralny charakter tych miejsc podkreślały ustawione pośrodku nich religijne figury (CAVEnago 1988).

Jedną $z$ najokazalszych nekropolii epidemicznych, zachowanych do naszych dni, jest cmentarz zbudowany w Zdziarze nad Sazawa (Ryc. 4A) $z$ inicjatywy opata tamtejszego klasztoru cystersów Václava Vejmluvy (1680-1738) dla ofiar epidemii dżumy, która w 1709 r. nawiedziła Morawy. Cmentarz ten został zaprojektowany przez Johanna Blasiusa Aichla (1677-1723) na planie trójkąta, $z$ owalnymi kaplicami umieszczonymi w wierzchołkach i połaczonymi murem o falistym przebiegu. Ustawiona na środku figura anioła dmacego w trąbę miała przypominać odwiedzającym cmentarz, że spoczywajacy na nim zadżumieni oczekuja, tak jak wszyscy inni zmarli, na zmartwychwstanie na Sądzie Ostatecznym i dlatego należy zachować ich w modlitewnej pamięci, prosząc o darowanie im grzechów (ŠANDEROVÁ 2010).

Ludzie nie chcieli jednak $z$ reguły pamiętać o bliźnich zabranych przez zarazę, ponieważ, jak zauważył Valleriole, ich los przypominał o straszliwym, powracajacym co kilkadziesiąt lat zagrożeniu (VALLERIOLE 1566). Miejsca pochówku ofiar epidemii bywały więc $z$ reguły nieoznaczane i wypierane ze świadomości na tyle zdecydowanie, że, jak odnotował Giovanni Battista Valentino (przed 1656-1735), mieszkańcy Neapolu już w kilka lat po nękającej ich straszliwej zarazie tak dalece zapomnieli o niej, że urządza- 
A

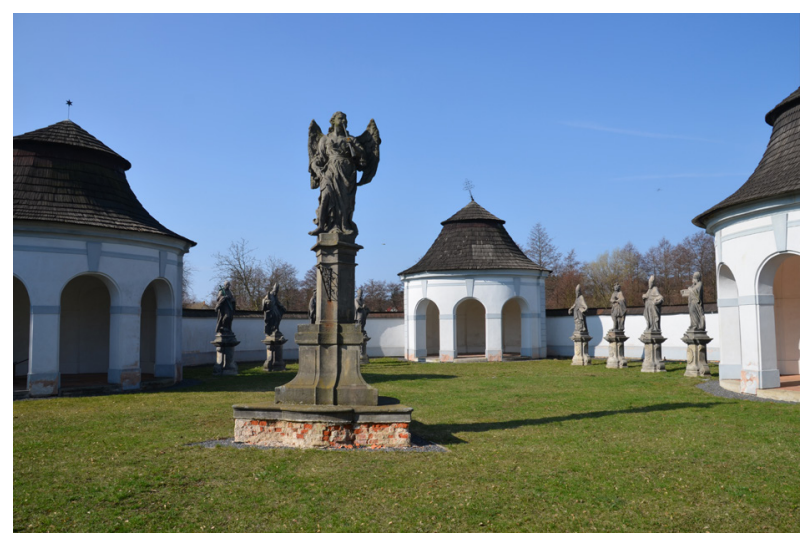

$\mathbf{C}$

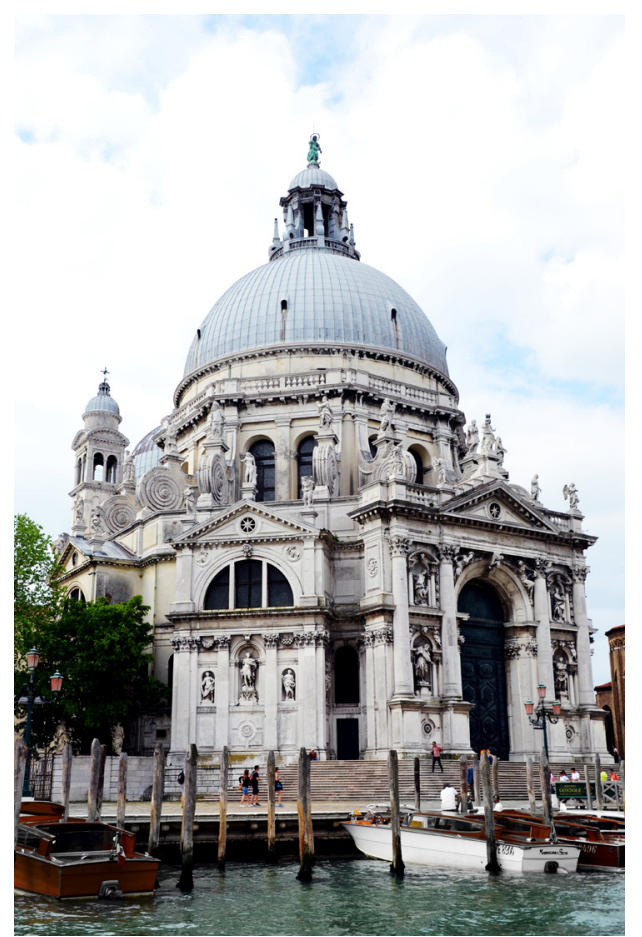

B

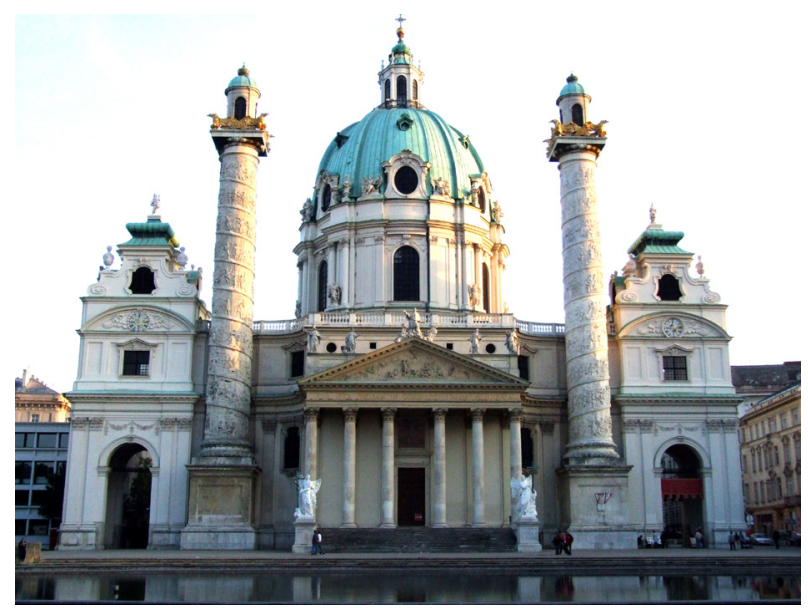

D

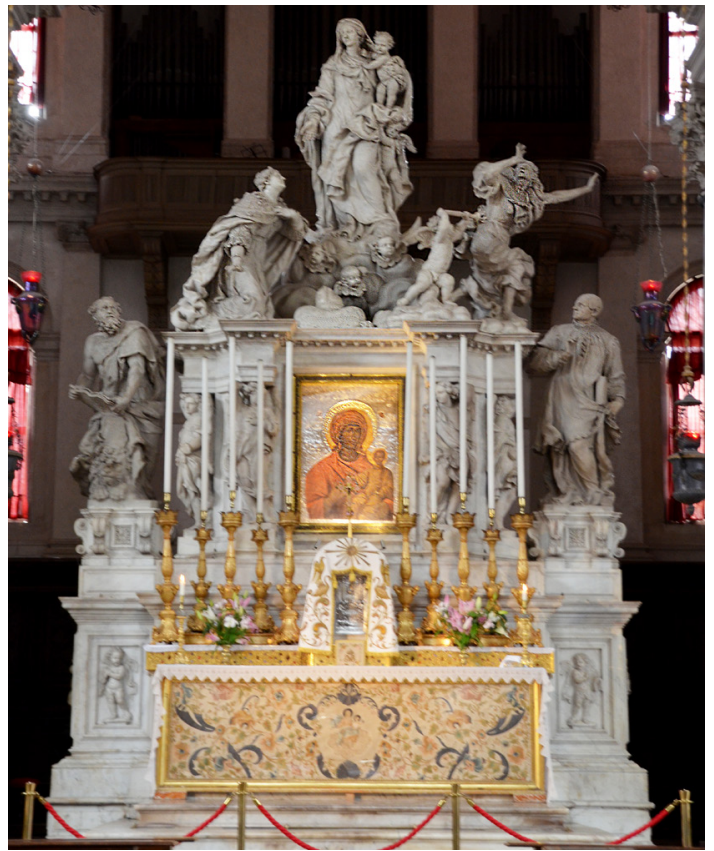

Ryc. 4. Cmentarz epidemiczny i kościoły wotywne za ustanie epidemii. A) Cmentarz epidemiczny w Zdziarze nad Sazawa, zaprojektowany przez Johanna Blasiusa Aichla, rozpoczęty 1709 (fot. Michał Kurzej). B) Kościół Hl. Karl Borromäus w Wiedniu, zaprojektowany przez Johanna Fischera von Erlach, 1716-1737 (fot. Kinga Blaschke). C) Kościół Santa Maria della Salute we Wenecji, zaprojektowany przez Baldassara Longhenę, 1631-1687 (fot. Michał Kurzej). D) Ołtarz główny kościoła Santa Maria della Salute w Wenecji, Giusto Le Court, 1670 (fot. Michał Kurzej).

li pikniki na masowym grobie uśmierconych przez nia ludzi w Grotta degli Sportiglioni, jedzacc i pijąc kilka stóp ponad szczatkami krewnych i znajomych (VALENTINO 1674).

Znacznie łatwiejsza do zaakceptowania od cmentarza, architektoniczna forma upamiętnienia zarazy i jej ofiar były kościoły wotywne, dedykowane Bogu i świętym chroniącym od moru, w podzięce za ustanie epidemii. Budowle takie nie przypomniały bowiem bezpośrednio o wielkiej liczbie zgonów spowodowanych przez epidemię, ale uświadamiały, że istnieje siła potężniejsza do choroby, która także w przyszłości może powstrzymać jej niszczącą moc.
Kościoły wotywne za ustanie zarazy były lokowane zarówno na obrzeżach miast w miejscu pochówku zakażonych [czego przykładem może być efektowny kościół Sao Roque w Lizbonie, budowany według projektu Filippa Terziego (1520-1597) od 1570 r., a także skromny drewniany kościół św. Rocha w Tarnogrodzie, wystawiony około $1624 \mathrm{r}$. (DEPCZYŃSKI 1972)], jak i na eksponowanych parcelach w centrach miejscowości. Poczatkowo $z$ ich funkcja nie kojarzono określonych form architektonicznych, ale okazały kościół San Sebastiano w Mediolanie, budowany pod nadzorem Boromeusza przez Pelegrina Tibaldiego od 1577 r., wprowadził 
niejako zwyczaj upamiętniania wygaśnięcia epidemii świątyniami centralnymi, zwieńczonymi kopułami (BolognA 1988). Takie rozwiazanie, kojarzone $z$ pomnikowa wymowa wczesnochrześcijańskich martyrionów (RoVETTA 1989), zostało zastosowane w prestiżowych fundacjach państwowych, które miały uzmysławiać widzom, że Boża interwencja, kończąca w cudowny sposób dramat zadżumionych miast, była wyrazem nadzwyczajnej przychylności Najwyższego dla władz, którym podlegały te ośrodki. Efektowny kościół Santa Maria della Salute w Wenecji (Ryc. 4C), został wzniesiony przez Baldassara Longhenę (1598-1682) w celu realizacji uchwały senatu Najjaśniejszej Republiki Weneckiej, podjętej $z$ inicjatywy doży Niccoli Contariniego (1553-1631) w 1631 r. Owa okazała fundacja miała wyrazić wdzięczność dla Marii za wyjednanie wygaśnięcia epidemii w 1630 r. oraz zamanifestować potęge państwa weneckiego, zdolnego zarówno opierać się zarazie, jak i wznosić wspaniałe gmachy (WITTKOWER 1975, NIERO 1979). Zaprojektowany przez Johanna Bernharda Fischera von Erlach (1656-1723), na polecenie cesarza Karola VI (1685-1740), wielki Karlskirche w Wiedniu (Ryc. 4B), nie tylko stanowił wotum za skuteczne orędownictwo św. Karola Boromeusza podczas pomoru w 1713 r., ale także przypominał o zasługach władcy, pod którego mądrymi i pobożnymi rządami Cesarstwo zdołało, dzięki Bożej pomocy, ograniczyć straszliwe skutki zarazy (FERGUSSON 1974, SPIRITTI 2006).

Funkcja kościołów wotywnych za wygaśnięcie epidemii była także manifestowana w ich wystroju. W ołtarzach tych gmachów umieszczano zwykle okazałe obrazy przedstawiające świętych protektorów, klęczacych przed Trójca Swięta lub Matka Boska z Dzieciątkiem i wstawiających się za dotkniętymi zaraza miastami, wymalowanymi u ich stóp. Na obrazach tych ukazywano starannie wygląd miast lub ich charakterystycznych części, ale wahano się, na ile wiernie oddawać dramat nękajacej je epidemii. Realistyczne ukazanie ofiar zarazy, na które zdecydował się m.in. Luca Giordano w obrazie namalowanym w 1652 r. dla kościoła Santa Maria del Pianto w Neapolu (Ryc. 2C) (BoECKL 2000), przypominało wprawdzie $z$ jak wielkiego nieszczęścia uwolniło ludzi Boże Miłosierdzie, ale mogło też zachęcać bluźnierców do stwierdzenia, że nie tyle należy dziękować Bogu za ocalenie części wiernych, ile pytać, dlaczego dopuścił On do śmierci tak wielu ludzi (GENTILCORE 2013). Wielu malarzy przedstawiało więc bardzo powściągliwie śmiertelne ofiary epidemii, albo też wyobrażało w dolnej strefie obrazu żywych zakażonych, wznoszacych w modlitwie ręce ku Bogu i świętym protektorom. Takie rozwiazanie, zastosowane m.in. przez Ludovica Lanę (1597-1646) w obrazie namalowanym dla Chiesa del Voto w Modenie po ustaniu epidemii w 1630 r. (BONOMETTI 1999), miało przekonywać wiernych, że „nadzieja czerpana $z$ religii" nie zostanie zawiedziona także w trakcie kolejnych zaraz.

W ołtarzu głównym weneckiego kościoła Santa Maria della Salute, poświęconym w 1670 r., spróbowano wyrazić takie przekonanie w sposób alegoryczny, bez przedstawiania jakichkolwiek okropieństw epidemii, dotykających społeczeństwo. Wokół cudownego obrazu Matki Boskiej, przed którym miano wymodlić ocalenie Wenecji, Giusto Le Court (właściwie Josse de Corte, 1627-1679) rozmieścił rzeźby ukazujące personifikację tego miasta w ceremonialnych szatach doży, która, wraz $z$ weneckimi patronami św. Markiem i św. Wawrzyńcem Giustinianim, prosi Jezusa i Marię o oddalenie plagi (Ryc. 4D) (MASON RinAldi 1979). Błagania te zostaja wysłuchane, ponieważ Matka Boska poleca aniołkowi przepędzić pochodnia zarazę, przedstawiona, zgodnie $z$ zaleceniami kompendium ikonograficznego Cesarego Ripy, pod postacia szpetnej $i$ wychudzonej starej kobiety o zmierzwionych włosach, ubranej w potargane szaty (Clemente 2019). Przerażenie rysujace się na twarzy personifikacji zarazy miało zapewne przekonać widzów, że epidemia, wzbudzająca paniczny strach w społeczeństwie, jest tak naprawdę bezsilna wobec cudownej Bożej reakcji, wyjednanej przez modlitwę Kościoła i roztropne wysiłki władz państwowych.

\section{POMNIKI MOROWE}

Alegoryczne przedstawienie zwycięstwa nad epidemia, umieszczone na ołtarzu weneckiego kościoła Santa Maria della Salute, powtórzono $z$ wymownymi modyfikacjami na Kolumnie Morowej (Pestsäule) na Graben w Wiedniu (Ryc. 5C), wzniesionej w 1687-1693, według projektu Johanna Fischera von Erlach i Paula Strudla (ok. 1648-1708). Miłosierny Bóg został na niej ukazany w trzech Osobach, a grono świętych orędowników rozszerzono do kilkunastu postaci. W miejsce uniwersalnej alegorii władzy państwowej przedstawiono aktualnie panujacego cesarza Leopolda I (1640-1705), a na jego modlitwy odpowiada bezpośrednio personifikacja Wiary z krzyżem, zachęcajaca aniołka, aby za pomoca pochodni przypalał upadajaca dramatycznie na plecy stara wychudzona kobietę, wyobrażajaca epidemię (Ryc. 5D) (COUDENHOVE 1958). Wzmożenie artystycznej „opowieści" o wpływie niebiańskiej interwencji na wygaśnięcie epidemii w Wiedniu w 1679 r. 
$\mathbf{A}$

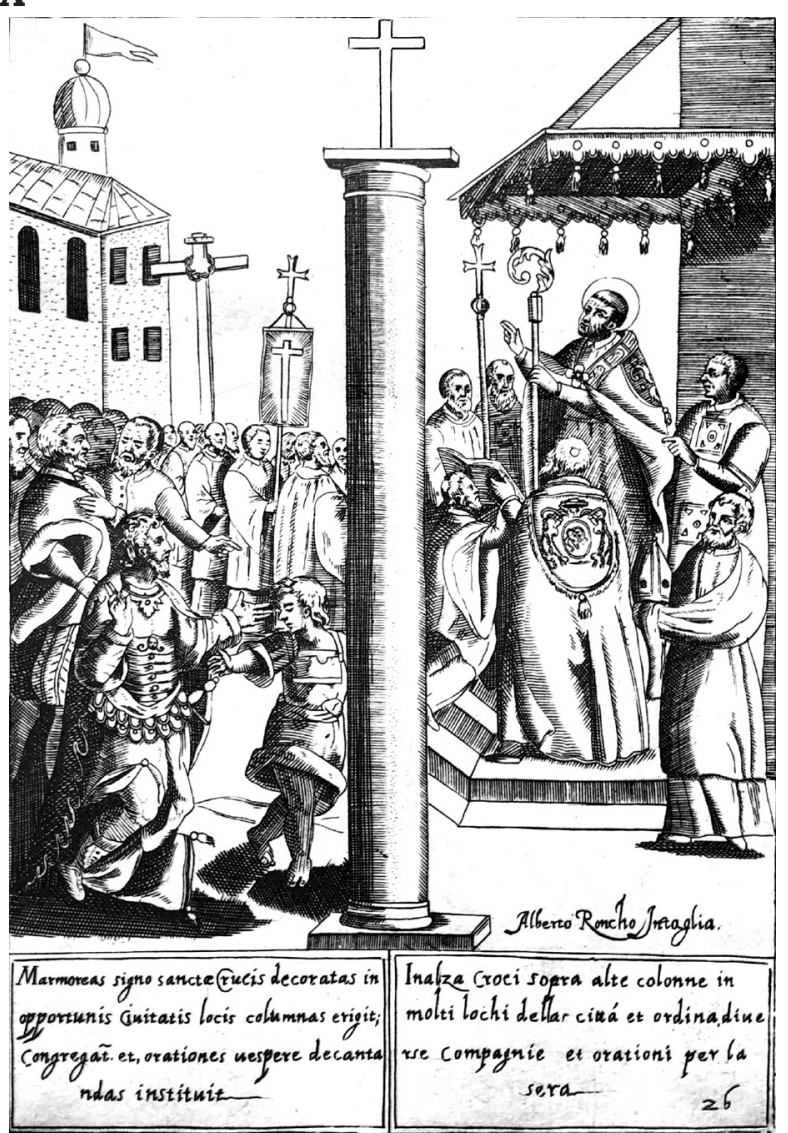

C

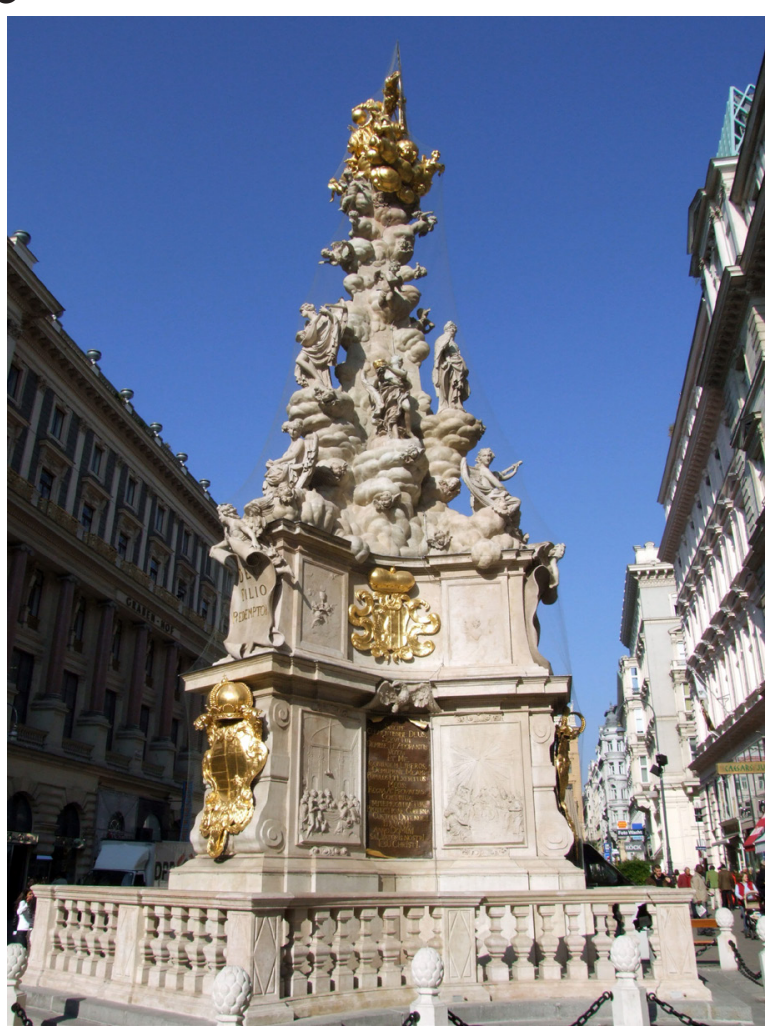

Ryc. 5. Kolumny morowe. A). Alberto Ronchi, Św. Karol Boromeusz święcący kolumnę $z$ krzyżem w Mediolanie w roku 1577, święcący miedzioryt,
$\mathbf{B}$
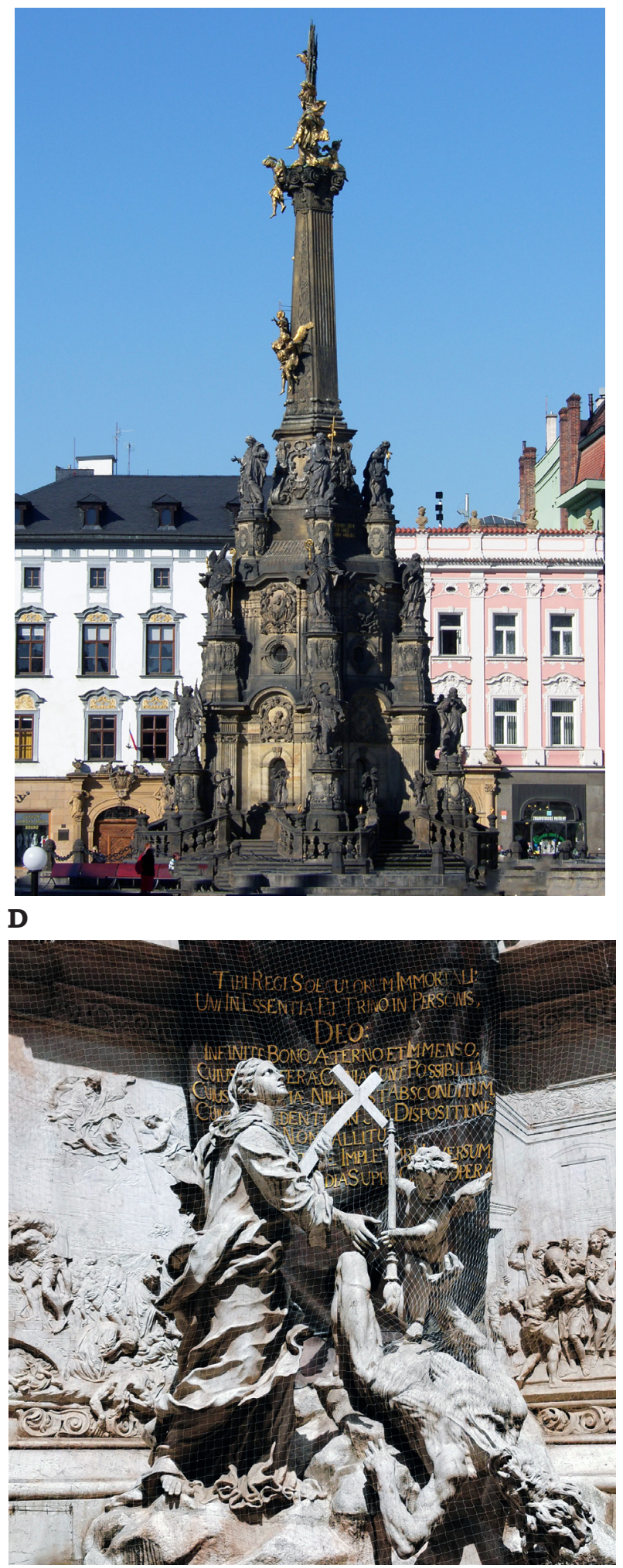

1610. B) Kolumna Trójcy Świętej w Ołomuńcu, zaprojektowana przez Wenzela Rendera, 17141716 (fot. Michał Kurzej). C) Kolumna morowa w Wiedniu, zaprojektowana przez Johanna Fischera von Erlach i Paula Strudla, 1687-1693 (fot. Kinga Blaschke). D) Kolumna morowa w Wiedniu, scena pokonania zarazy (fot. Michał Krasny). 
oraz o przyczynieniu się władzy cesarskiej do tego szczęśliwego zakończenia plagi wynikało zapewne $z$ faktu, że kolumna morowa nie była elementem wyposażenia kościoła, którego wymowę mogli wyjaśniać duchowni w trakcie kazań. Jako pomnik oddziałujący przez cały dzień na przechodniów w intensywniej uczęszczanej przestrzeni miejskiej, musiała ona narzucać swój przekaz w sposób jednoznaczny, dosadny i silnie wpływajacy na emocje widzów. Oglądajace ją osoby miały bowiem nabrać przekonania, że monarchia habsburska, wchodzaca właśnie w szczytowy okres swojej potęi, może zabezpieczyć swoich poddanych nie tylko przed wrogimi nacjami, ale także $z$ Bożą pomoca jest zdolna chronić ich dość skutecznie przed najbardziej zabójczymi klęskami naturalnymi (BROCKMANN 2008).

Tak złożonego przekazu nie zawierały wcześniejsze kolumny morowe budowane we Włoszech od poczattku XVI w. i spopularyzowane przez Karola Boromeusza. Po ustaniu epidemii dżumy, nękajacej Mediolan w 1576 r., poświęcił on trzydzieści trzy kamienne kolumny zwieńczone metalowymi krzyżami w miejscach, w których w trakcie zarazy odprawiano msze polowe (Ryc. 5A) (RICHTER 2009). Dla osób nieznajacych okoliczności zbudowania kolumn, ich wymowa jako pomników-wotów za ustanie pomoru była jednak zupełnie nieczytelna. Dlatego przekaz ten trzeba było przypominać w trakcie specjalnych nabożeństw organizowanych przez powołane specjalnie $\mathrm{w}$ tym celu bractwo, a także upowszechniać go za pomoca wydawnictw (STEWARD 2017). Wysiłki te okazały się dość skuteczne, ponieważ pomniki epidemiczne $\mathrm{w}$ formie kolumn $z$ krzyżami zaczęto budować na wzór mediolańskich w całej Europie, w tym także na ziemiach polskich m.in. w Nowym Wiśniczu (1642), Olchawie (1654), Szczebrzeszynie (1672), Fajsławicach (poczatek XVIII w.), Włodawie (1766) i w podkrakowskich Bronowicach (1776) (SEWERYN 1958, DUTKIEWICZ i współaut. 2018). Skromne formy takich monumentów i ich nieoczywista wymowa sprawiły jednak, że zaczęto podejmować próby ich wzbogacenia.

Kolumny $z$ krzyżami, wznoszone staraniem biskupa genewskiego Franciszka Salezego (1567-1622) na terenie jego diecezji, oprócz przekazu wotywnego, głosiły także treści kontrreformacyjne, propagujac kult znaku krzyża, odrzucany bardzo zdecydowanie przez tamtejszych kalwinistów (RICHTER 2009). Takie dopełnienie programu treściowego kolumn morowych było oczywiste w epoce nowożytnej, w której protestancka herezję opisywano bardzo często jako duchowa zarazę, infekujaca $z$ wielka siłą zdrowa katolicką społeczność. Nie należy się więc dziwić, że zaadaptowano je także w kolumnach budowanych w krajach Rzeszy i w Królestwie Węgierskim, rządzonych przez Wittelsbachów i Habsburgów, umacniajacych swoją władzę poprzez katolicka unifikację wyznaniowa swych poddanych. Protestancka „zaraza”, dotykajaca te kraje, był luteranizm rozwijający, na równi $z$ katolicyzmem, kult krzyża. Dla określenia katolickiej tożsamości kolumn morowych umieszczano wiec na nich wizerunki odwołujace się do katolickiej wiary w orędownictwo Matki Boskiej i świętych, kwestionowanej zdecydowanie przez luteranów. Kluczowe znaczenie dla rozpowszechnienia takiego rozwiazania miały kolumny na Marienplatz w Monachium (1638), na Rynku Staromiejskim w Pradze (1650) i na Rynku w Bratysławie (1675), które zwieńczono figurami Marii z Dzieciątkiem lub Niepokalanej (ŠORM i KRAJČA 1939).

Z czasem wokół kolumny, przybierającej nieraz formę słupa obłoku wynoszacego Trójcę Święta, zaczęto umieszczać coraz liczniejsze figury świętych, dodając do powszechnie czczonych obrońców od moru, Sebastiana, Rocha, Rozalii i Alojzego Gonzagi, protektorów państw, prowincji i miast, a także patronów parafii i domów zakonnych, znajdujaccych się w danej miejscowości. Wspomniana kolumna wiedeńska była zapewne prototypem takiego rozwiazania, ale bardzo szybko została przyćmiona przez znacznie okazalsze pomniki zbudowane między innymi w Ołomuńcu (Ryc. 5B) i w Uniczowie (JEMELKOVÁ i współaut. 2008). Do połowy XVIII w. kolumny morowe wystawiono na niemal wszystkich rynkach w Austrii, w Królestwie Czeskim i w Królestwie Węgierskim, czyniąc $z$ nich wyraziste znaki bezwzględnego panowania na tych ziemiach religii katolickiej i dynastii habsburskiej (ScHIKOLA 1985). Rozpowszechnienie tych pomników nastapiło w szczęśliwym czasie, w którym na terenie Europy środkowej wygasły epidemie dżumy, a cholera nie pokazała jeszcze swej niszczacej siły (JORI 2020). Osoby oglądające kolumny morowe w dwóch ostatnich tercjach XVIII w., wyczytywały więc $z$ nich zapewne pocieszajaca naukę, że przywrócenie prawowiernej religii i ugruntowanie światłej władzy cesarskiej lub królewskiej chroni ich skutecznie przed pomorami, które tak strasznie doświadczały ich przodków.

\section{KONKLUZJA}

Według świadectwa Jeana Baptiste'a Radeta (1752-1830) widzowie oglądajacy na Salonie w Paryżu w 1781 r. obraz Jaçquesa Louisa Davida (1748-1825) Św. Roch oredujacy za zadżumionymi, obchodzili szeroko to dzieło i nie patrzyli na nie, obawiając się 
zarażenia od przedstawionych na nim ofiar epidemii (RADET 1781). Relacja ta pokazuje, jak wielki wpływ mogły wywierać dzieła sztuki na wyobraźnię ludzi w epoce nowożytnej, potwierdzajac wnioski z klasycznej ksiażki Davida Freedberga. Stwierdził on, że zdecydowana większość ludzi nie umiała dostrzec granicy pomiędzy rzeczywistościa i światem kreowanym przez obrazy, ryciny, rzeźby i budowle. Za pomoca tych tworów można było zatem narzucać im mocno zmodyfikowana, czy wręcz sfałszowana wizję świata, w którym przyszło im żyć (FREEDBERG 2005). Ewidentny „tryumf śmierci” zakrywano więc dziełami sztuki, wskazującymi lub może pozorujacymi oznaki nadziei, pozwalające części zwykłych ludzi nie oszaleć ze strachu przed pomorem, a władzom, w znacznym stopniu bezsilnym wobec mocy natury, zachować przynajmniej część autorytetu.

Wydaje się zatem, że badania nad artystyczną odpowiedzią na epidemie należy podporządkować opinii Freedberga o sztuce nowożytnej, iż nie powinno się nazywać ja przedstawiajaca przede wszystkim dlatego, że nie była ona biernym opisem rzeczywistości, ale jednym $z$ najważniejszych kształtujących ją elementów (FREEDBERG 2005). Można by zatem, w ślad za Henrim H. Molaretem i Jacqeline Brossollet, opisywać zarazę jako „nieznane źródło inspiracji artystycznej” (MOllaret i BRossollet 1965), albo wręcz uznać zainspirowane przez nia dzieła sztuki za komponent epidemii, która, według Anny Di Veroli i Alda Gerbina (DI VEROLI 2014, GERBINO 2014), jest nie tylko fenomenem przyrodniczym, ale złożonym kompleksem różnych zjawisk, wśród których olbrzymia rolę odgrywa reakcja społeczeństw i poszczególnych osób na śmiertelne zagrożenie.

Streszczenie

Obrazy ukazujące zarazę $\mathrm{w}$ epoce nowożytnej miały nie tylko przedstawiać zmiany chorobowe na ciałach osób lub dramatyczny przebieg epidemii w społeczeństwie, ale także przekonywać widzów, że władze kościelne i państwowe panuja w znacznym stopniu na plaga dotykająca tysiące osób. Lazarety o bogatych formach architektonicznych służyły nie tylko izolacji chorych, ale manifestowały troskę państwa o ich los, a zarazem ukrywały ich cierpienie przed zdrowa częścia społeczeństwa. Kościoły i pomniki upamiętniające epidemie głosiły zaś, że Boże Miłosierdzie uwalniało wielokrotnie ludzi z epidemicznej opresji.

\section{LITERATURA}

Aurigemma M. G., 1998. Nati sotto Vesalio. La verità dell'imagine. [W:] Scienza e miracoli nell'arte del '600. Alle origini della medicina moderna. Rossi S. (red.). Electa, Milano, 90101.
BASEDOW J. B., 1774. Elementarwerk für die Jugend und ihre Freunde. Kupfersammlung. S.L. Crusius, Berlin-Dessau, t. 1.

BERGOLDT K., 2006. Die Pest. Geschichte des Schwarzen Todes, Beck C.H., München.

BERTRAND R., 1992. L'iconographie de la peste de Marseille ou la longue mémoire d'une catastrophe. [W:] Images de la Provence. Les représentations iconographiques de la fin du Moyen Age au millieu du $\mathrm{XX}^{\mathrm{e}}$ siècle. Publications de l'université de Provence, Aix-de-Provence, 75-83.

BoECKL C., 2000. Images of plague and pestilence. Iconography and iconology. Truman State University Press, Kirksville.

Bologna G, 1988. Il civico tempio di S. Sebastiano. Biblioteca Trivulziana, Milano.

BonometTi P., 1999. Omobono. La figura del santo nell'iconografia. Secoli XIII-XIX. Silvana, Milano.

BROCKMANN T., 2008. Das Bild des Hauses Habsburg in der dynastienahen Historiographie um 1700. [W:] Bourbon, Habsburg, Oranien: konkurrierende Modelle im dynastischen Europa um 1700. KampmanN C., KRAUSE K., KREMS E. B., TIscher A. (red.). Böhlau, Köln Weimar, $27-57$.

BURZER K., 2011. San Carlo Borromeo. Konstruktion und Inszenierung eines Heiligenbildes im Spannungsfeld zwischen Mailand und Rom. Deutscher Kunstverlag, Berlin-München.

Cavenago V., 1986. Il Lazzaretto. Storia di un quartiere di Milano., NED, Milano.

Cavenago V., 1988. Cimiteri. [W:] Dizionario della Chiesa Ambrogiana. MAJO A. (red.). NED, Milano, t. 2, 833-836.

CipPola C. M., 1981. Fighting the plague in seventeenth-century Italy. University of Winsonsin Press, Madison.

Clemente M., 2019. White marble and black death. Giusto Le Court at the Salute. Il marmo biancho e la peste nera. Giusto Le Court alla Salute. Marsilio, Venezia.

Coudenhove G., 1958. Die Wiener Pestsäule: Versuch einer Deutung mit einer Abhandlung Die Dreifaltigkeitssäule als Kunstwerk. Herold, Wien.

DE Coo J., 1965. Ontraadseling van Barok-sculptuur in de St.-Pauluskerk te Antwerpen, Koniklijk Museum voor Schone Kunsten Antwerpen. Jaarboek, 323-242.

DEPCZYŃSKI W., 1975. Parafia Tarnogród. Nasza Przesłość 32, 125-207.

Dinges M. 1995. Pest und Staat. Von der Institutionengeschichte zur sozialen Konstruktion? [W:] Neue Wege in der Seuchengeschichte. Dinges M., Schlich T. (red.). Franz Steiner, Stuttgart, 7-24.

DI VEROLI A., 2014. La peste. Colpa, peccato e destino nella litteratura italiana. Edizioni ETS, Pisa.

DOMPNIER B., 2006. La dévotion à Charles Borromée dans la France du XVIII siècle. Représentations d'un saint et histoire de son culte. Studia Borromaica 20, 253-292.

DUTKIEWICZ M., DABBSKI, M., DURLAK W., 2018. Obiekty sacrum $w$ założeniach rezydencjonalnych łeczyńskiego przełomu Wieprza. Prace Komisji Krajobrazu Kulturowego 32, 57-70.

ECONOMOPOULOS H., 1998. Antonio Giraldi detto Cavalier Coppa, Verona suplice ai piedi della Trinità con l'intercesione della Vergine per liberazione della pestilenza del 1630. [W:] Scienza e miracoli nell'arte del '600. Alle origini della medicina moderna. Rossi S. (red.). Electa, Milano, 340-341. 
EMISON P., 2012. The Italian renaissance and cultural memory. Cambridge University Press, New York.

FERGUSSON F. D., 1974. St Charles' Church, Vienna. The iconography of its architecture. J. Soc. Architect. Hist. 29, 318-326.

FREEDBERG D., 2005. Potega wizerunków. Studia $z$ historii $i$ teorii oddziatywania. Wydawnictwo Uniwersytetu Jagiellońskiego, Kraków.

FOLGHERAITER A., 1994. I dannati della peste. Tre secoli di stragi nel Trentino (1348-1636). Curcu \& Genovese, Trento.

FRACASTOR H., 1546. De contagione et contagiosis morbis. heredes Lucaeantonii Juntae Florentini, Venetia.

Furlan C., MASON S., Scienza e miracoli nel la pittura veneta del Seicento. [W:] Scienza e miracoli nell'arte del '600. Alle origini della medicina moderna. Rossi S. (red.). Electa, Milano, 116-133.

GASTALDI H., 1684. Tractatus de avertenda et profliganda peste politico-legalis. Typographia Manolessiana, Bononia.

GatTa S., 1998. Religiositá ed ex voto nell'epoca barocca. [W:] Scienza e miracoli nell'arte del '600. Alle origini della medicina moderna. Rossi S. (red.). Electa, Milano, 166-169.

GAZZANigA V., 1998. "Mox, longe, tarde, cede, recede, redi". Epidemie di peste nell'Italia del Seicento. [W:] Scienza e miracoli nell'arte del '600. Alle origini della medicina moderna. Rossi S. (red.). Electa, Milano, 52-59.

GENTILCORE D., 2013. Tempi si calamitosi. Epidemic disease and public health. [W:] A companion to early modern Naples. ASTARITA T. (red.). Brill, Leiden, 281-306.

Gerbino A., 2020. Corpi e anime infette. Motivi cairologici. [W:] I messaggeri dell'Apocalisse. Le epidemie tra medicina, storia, filosofia $e$ arte. JORI A. (red.). Nova Ipsa Editore, Palermo, 447-481.

Giussano G. P., 1610. Vita di San Carlo Borromeo, prete cardinale del titolo di Santa Parassede, arcivescovo di Milano. Stamperia della Camera Apostolica, Roma.

HENDERSON J., 2019. Florence under siege. Survive plague in early modern city. Yale University Press, New Haven.

JEMELKOVÁ S., ZAPALKOVÁ H., ONDRUŠKOVÁ M., 2008. Holy Trinity Column, Olomouc. Olomouc Museum of Art, Olomouc.

Jones P. M., 2005. San Carlo Borromeo and plague imagery in Milan and Rome. [W:] Hope and Healing. Painting in Italy in the time of plague. BAILEY G. A., (red.). University of Chicago Press, Chicago 65-96.

JoRI A., 2020. Le grandi epidemie nell'età moderna e contemporanea. [W:] I messaggeri dell'Apocalisse. Le epidemie tra medicina, storia, filosofia e arte. JORI A. (red.) Nova Ipsa Editore, Palermo, 120-154.

LOLLOBRIGIDA C., 1998, Guillame Courtois, La peste $e$ il seppelimento dei morti. [W:] Scienza e miracoli nell'arte del '600. Alle origini della medicina moderna. Rossi S. (red.). Electa, Milano, 254.

MANZI L., 1967. La peste e l'arte in Bologna. Rapporti e testimonianze. Strenna Storica Bolognese $17,255-280$.

MARSHALL L., 2009. A new plague saint for Renaissance Italy. Suffering and sanctity in nar rative cycles of Saint Roch. [W:] Crossing cultures. Conflict, migration, convergence, ANDERsoN J. (red.). Miegenyah Press, Melbourne, 153-188.
MARTIN P., 2020. Les religions face aux épidémies. De la peste à la Covid-19, Editions du Cerf, Paris.

MASON RINALDI S., 1979. La peste e le sua immagini nella cultura figurativa veneziana [W:] Venezia e la peste 1384-1797. Marsilio, Venezia, 209-224.

Micheli G., 1998, Anonimo. La peste in Trastevere. [W:] Scienza e miracoli nell'arte del '600. Alle origini della medicina moderna. RossI $\mathrm{S}$. (red.). Electa, Milano, 339-340.

MollareT H. H., BROSSOLleT J., 1965. La peste, source méconnue d'inspiration artistique. Koniklijk Museum voor Schone Kunsten Antwerpen, Jaarboek, 3-112

NiERO A., 1979. I templi del Redentore e della Salute. Motivazioni teologiche. [W:] Venezia e la peste 1384-1797. Marsilio, Venezia, 294-298.

NUÑEZ BELTRÁN M. A., 2000. La oratoria sagrada de la época del barroco: doctrina, cultura $y$ actitud ante la vida desde los sermones sevillanos del siglo XVII. Universidad de Sevilla, Sevilla.

PORZIO A., 1984, Immagini della peste del 1656. [W:] Civiltà del Seicento a Napoli. CASSANI S. (red.). Electa, Napoli, t. 2, 51-57.

Puglisi C. R., 1995 Guido Reni's "Pallione del voto" and the Plague of 1630. Art Bull. 77, 402-412.

RADET J. B., 1781. Réflexions joyeuses d'un garcon de bonne humeur sur les tableaux exposés au Salon en 1781. Libraire de la veuve Vatel, Paris.

RELAZIONE, 1661. Relazione della solentissima festa fatta [...] per lo scioglimento del voto alla mesima città nell'anno 1656, Francesco Pace, Napoli.

RicHTER K., 2009. Triumph des Kreuzes. Kunst und Konfession im Letzten Viertel des 16. Jahrhunderts. Deutscher Kunstverlag, BerlinMünchen.

Rossi Di MARIgnano F. A., 2010. Carlo Borromeo. Un uomo, una vita, un secolo. Gruppo Mondatori, Milano.

Rousseau J. J., 1978. Wyznania. Ossolineum, Wrocław.

ROVETTA A., 1989. Due chiese a pianta centrale nella Milano borromaica: S. Sebastiano e S. Alessandro. [W:] L'architettura a Roma e in Italia (1580-1621). SPAGNESI G. (red.). Centro di studi per la storia dell'architettura, Roma, t. $2,217-221$.

ŠANDEROVÁ J., 2010. Dolni hřbitov. [W:] Kostel sv. Jana Nepomuckého na Zeléne Hoře, Horyna M. (red.). Narodní Ústav Památkové Péče Telč, 232-233.

Schmitz-EICHHOF M. T., 1977 St. Rochus. Ikonographische und medizinhistorische Studien. Hansen, Köln.

SchÜTZE S., VIREY-WALlon A., 1996. Aristide de Thèbes, Raphaël et Poussin. La représentation des affetti dans les grands tableaux d'histoire de Poussin des années 1620-1630. [W:] Nicolas Poussin (1594-1665). MÉROT A. (red.). Réunion des Musées Nationaux, Paris, t. 2, 575-589.

Schikola G., 1985. Das öffentliche sakrale Denkmal in den habsburgischen Ländern. Die Auswirkung der Wiener Pestsäule. [W:] Studien zur europäischen Barock- und Rokokoskulptur. KALINOWSKI K. (red.). Wydawnictwo Naukowe Uniwersytetu im. Adama Mickiewicza, Poznań, 253-283.

SEWERYN T., 1958. Kapliczki i krzyże przydrożne $w$ Polsce, PAX, Warszawa. 
SONNINO E., 1998. „Di qui cominciò qualche terrore considerabile nella città di Roma". Populazione e sanità nel XVII secolo. [W:] Scienza e miracoli nell'arte del '600. Alle origini della medicina moderna. Rossi S. (red.). Electa, Milano, 60-69.

ŠORM A., KRAJČA A., 1939. Mariánské sloupy $v$ Čechách a na Moravě. Přispěvky $k$ studiu barokni kultury. Nakladatelství Antonína Dan̆ka, Praha.

SPIRITTI A., 2006. Da Carlo Borromeo a Carlo VI. Iconografia politica nella Karlskirche di Vienna. Studia Borromaica 20, 293-316.

STEVENS CRAWSHAW J. L., 2012. Plague hospitals. Public health for the city in early modern Venice. Routledge, London and New York.

STEWARD P. A. V., 2017. Staging the crosses in the ritual city. Stational crosses and confraternal spectacle in the renaissance Milan. [W:] Space, place, and motion. Locating confraternities in the late medieval and early modern city. BULlen PRESCIUTTI D. (red.). Brill, Leiden, 217-243.
UlBRICHT O., 2004. Pesthospitäler in deutschsprachigen Gebieten. [W:] Die leidige Seuche. Pest-Fälle in der Frühen Neuzeit. ULBRICHT O. (red). Bohlau, Köln, 295-325.

VAlENTINO G. B., 1674. Napole scontrafatto dopo la peste. Francesco Pace, Napoli.

VAlleriole F., 1566. Traicte de la peste. Antoine Gryphius, Lyon.

VLOERS P., 1658. Wonderbaere mirakelen vanden H. Roosen-krans, Godt-gaf Verhulst, Antwerpen, t. 1.

WITTKOWER R., 1975. Studies in the Italian Baroque. Thames and Hudson, London, 125152.

Wouk E. H., 2016. From Death to Print. Marcantonio Raimondi's "Morbetto" and the power of engravings in Raphael's Rome. [W:] Marcantonio Raimondi, Raphael and the image multiplied. Wouk E. H., MORRIS D. (red.). Manchester University Press, Manchester, 47-65.

KOSMOS Vol. 70, 3, 535-549, 2021

\section{PIOTR KRASNY}

Institute of History of Art, Jagellonian University, Cracow, 53 Grodzka Str., 31-001 Kraków, E-mail: piotr.krasny@uj.edu.pl

\section{ART AND EPIDEMIC IN EARLY MODERN PERIOD}

\section{Summary}

In the early modern era the images showing the plague were intended not only to depict the lesions on the bodies of people or the dramatic course of the epidemic in society, but also to convince viewers that Church and state authorities largely reign over the scourge, affecting thousands of people. Impressive lazarets served not only to isolate the sick, but also manifested the state's concern for their fate, and at the same time concealed their suffering from a healthy part of society. Churches and monuments commemorating pestilences proclaimed that God's Mercy had freed people from epidemic oppression many times.

Key words: epidemic in early modern art, impact of the epidemic on architecture, religion against the epidemic, state authorities against the epidemic 